\title{
Pengaruh Model Pembelajaran Scramble Berbantuan Media Gambar terhadap Hasil Belajar IPA
}

\author{
L. Widi Astriani ${ }^{1}$, I Km. Sudarma ${ }^{2}$ \\ ${ }^{1}$ Jurusan PGSD, ${ }^{2}$ Jurusan TP, FIP, Universitas Pendidikan Ganesha \\ Singaraja, Indonesia \\ e-mail: astriani.widi@yahoo.com ${ }^{1}$, sudarmadede@gmail.com²
}

\begin{abstract}
Abstrak
Permasalahan rendahnya hasil belajar IPA yang ditemukan pada siswa kelas III di Gugus II Kecamatan Kubutambahan menjadi masalah utama untuk dilakukan penelitian ini. Rendahnya hasil belajar IPA diduga karena guru-guru dalam pembelajaran cenderung menggunakan metode yang kurang inovatif. Oleh karena itu penelitian ini dilakukan dengan tujuan untuk mengetahui pengaruh yang signifikan model pembelajaran scramble berbantuan media gambar terhadap hasil belajar IPA siswa kelas III di SD Gugus II Kecamatan Kubutambahan Tahun Pelajaran 2017/2018. Populasi penelitian adalah siswa kelas III di SD Gugus II Kecamatan Kubutambahan yang berjumlah 194 siswa. Sampel penelitian adalah siswa kelas III SDN 1 Kubutambahan yang berjumlah 36 siswa dan SDN 6 Kubutambahan yang berjumlah 35 siswa. Data hasil belajar IPA dikumpulkan dengan metode tes bentuk pilihan ganda. Data hasil penelitian tersebut dianalisis dengan teknik statistik deskriptif dan statistik inferensial (uji-t). Hasil penelitian menunjukkan bahwa: (1) rata-rata hasil belajar siswa kelompok eksperimen adalah 25,33 berada pada kategori sangat tinggi, (2) rata-rata hasil belajar siswa kelompok kontrol adalah 17,00 berada pada kategori sedang, (3) Hasil uji hipotesis dengan menggunakan uji-t, diperoleh $t_{\text {hitung }}$ lebih besar daripada $t_{\text {tabel }}(10,6>1,99)$. Berdasarkan hasil analisis data tersebut dapat disimpulkan bahwa terdapat pengaruh yang signifikan model pembelajaran scramble berbantuan media gambar terhadap hasil belajar IPA siswa kelas III di SD Gugus II Kecamatan Kubutambahan Tahun Pelajaran 2017/2018.
\end{abstract}

Kata Kunci: Gambar, Hasil Belajar IPA, Scramble

\begin{abstract}
The problem of low students result in science studies it can be found in the third-grade students in cluster two in Kubutambahan sub-district as a major problem why this study should be conducted. The low learning result of science studies because of the teachers in teaching the students less of using an innovative method based on the teacher. Because of that, this study should be conducted to know the significance of learning model scramble it helps by media using picture towards students learning of science studies in third-grade student in SD cluster two Kubutambahan sub-district in academic year 2017/2018. The population of their study was the students of third grade in cluster two of SD in Kubutambahan sub-district the total were 194 students. The sample of this study was the students of the third grade in SDN 1 Kubutambahan were 36 students and SDN 6 Kubutambahan the total was 35 students. The process of data collection using test method in the form of multiple choice. the data result of this study was analyzed by statistics descriptive technique and inferential statistics (uji-t). the result showed: (1) the average of the student results in the experiment group were 25,33 which could be categorized very high, (2) the average of the students result in control group were 17,00 which could be categorized medium, (3) the result hypothesis test using uji-t technique, obtained $t_{\text {-hitung }}$ bigger than $t_{\text {tabel }}(10,6>1,99)$. Based on result analysis data could be concluded that there was the influence which was significance towards scramble learning method which helps by media using picture towards students result in learning science studies of the thirdgrade students in SD cluster two Kubutambahan sub-district in academic year 2017/2018.
\end{abstract}

Keywords: Picture, The Learning Result of Science Studies, Scramble 


\section{Pendahuluan}

Belajar dan pembelajaran merupakan suatu kegiatan yang melibatkan seseorang dalam rangka memperoleh pengetahuan. keterampilan dan nilai-nilai positif dengan memanfaatkan berbagai sumber untuk belajar baik dikelas maupun di luar kelas. Pembelajaran dapat melibatkan dua pihak yaitu siswa sebagai pembelajar dan guru sebagai pengajar atau fasilitator (Masnati, 2017). Pembelajaran merupakan interaksi antara pendidik dan peserta didik (Susanto, 2013). Dalam interaksi tersebut siswa menjadi subjek dalam pembelajaran, yang mana siswa terlibat secara penuh baik secara fisik maupun mental dalam proses pembelajaran untuk menggali pengetahuannya sendiri sedangkan guru hanya sebagai fasilitator dalam pembelajaran, sehingga akan membentuk sumber daya manusia (SDM) yang cerdas dan berkualitas. Hal tersebut sesuai dengan paradigma pembelajaran yang terjadi saat ini yaitu pembelajaran yang tadinya berpusat pada guru kini menjadi pembelajaran berpusat pada siswa, Terkait dengan hal tersebut pembelajaran di sekolah khususnya Sekolah Dasar perlu direncanakan dengan baik menggunakan model pembelajaran yang inovatif, menarik dan menyenangkan serta dengan menggunakan media pembelajaran guna menarik perhatian dan minat siswa untuk belajar, serta hasil belajar akan menjadi lebih optimal. Pembelajaran yang demikian harus terjadi pada semua mata pelajaran yang diterapkan di sekolah dasar, termasuk pembelajaran IPA.

IPA merupakan mata pelajaran yang wajib diberikan di sekolah dasar. Mata pelajaran ini memegang peranan yang sangat penting dalam kehidupan sehari-hari. IPA merupakan ilmu yang berkaitan dengan lingkungan alam dan diri sendiri. Susanto (2013:167) menyatakan bahwa "IPA adalah usaha manusia dalam memahami alam semesta melalui pengamatan yang tepat pada sasaran, serta menggunakan prosedur, dan dijelaskan dengan penalaran sehingga didapatkan suatu kesimpulan". Pada pembelajaran IPA siswa mempelajari diri sendiri dan alam sekitar. Siswa hendaknya dilibatkan secara langsung dalam menggali pengetahuannya sendiri, sedangkan guru hanya sebagai fasilitator dan pemandu dalam proses pembelajaran, serta pembelajaran hendaknya berkaitan dengan lingkungan alam atau lingkungan sekitar siswa untuk mempermudah siswa dalam memahami materi pembelajaran sehingga dapat memberikan pengalaman langsung dan kegiatan praktis untuk mengembangkan kompetensi agar siswa memahami alam sekitar secara ilmiah. Pendidikan IPA di Sekolah Dasar bermanfaat untuk memupuk rasa ingin tahu anak didik secara alamiah. Hal ini akan membantu peserta didik mengembangkan kemampuan bertanya dan mencari jawaban atas fenomena alam berdasarkan bukti serta mengembangkan cara berpikirnya. Oleh karena itu pembelajaran IPA di Sekolah Dasar diharapkan dirancang dengan menyenangkan, mampu menarik minat siswa, meningkatkan keaktifan siswa, menggunakan model pembelajaran yang inovatif, serta pada proses pembelajaran hendaknya digunakan suatu media pembelajaran untuk lebih meningkatkan motivasi siswa dalam belajar.

Namun fakta yang ditemukan dilapangan, pembelajaran IPA masih belum sesuai harapan. Dari hasil wawancara dengan tujuh guru mata pelajaran IPA di kelas III pada tanggal 8 dan 9 Desember 2017 di SD Gugus II Kecamatan Kubutambahan, didapatkan hasil yaitu: (1) dalam proses pembelajaran guru masih menggunakan metode ceramah, diskusi dan penugasan (2) masih kurangnya penggunaan media pembelajaran, (3) masih kurangnya keaktifan siswa dalam mengikuti proses pembelajaran.

Selain wawancara juga dilakukan pencatatan dokumen pada tanggal 8 dan 9 Desember 2017 yang diperoleh dari hasil rata-rata Ulangan Tengah Semester (UTS) dari guru mata pelajaran IPA kelas III. Berdasarkan nilai UTS tersebut didapatkan rata-rata hasil belajar IPA siswa dengan KKM 68 - 75 seperti yang disajikan pada tabel 1. berikut.

Tabel 1. Nilai UTS IPA Siswa Kelas III di Gugus II Kecamatan Kubutambahan

\begin{tabular}{cccccccc}
\hline \multirow{2}{*}{ Nama Sekolah } & \multirow{2}{*}{ KKM } & \multirow{2}{*}{$\begin{array}{c}\text { Jumlah } \\
\text { Siswa }\end{array}$} & \multirow{2}{*}{$\begin{array}{c}\text { Rata- } \\
\text { rata }\end{array}$} & & \multicolumn{2}{c}{ Tuntas } & \multicolumn{2}{c}{ Tidak Tuntas } \\
\cline { 7 - 9 } & & & & Jumlah & (\%) & Jumlah & (\%) \\
\hline SD Negeri 1 Kubutambahan & 75 & 36 & 70,33 & 21 & 28 & 15 & 41 \\
SD Negeri 2 Kubutambahan & 70 & 23 & 62,91 & 12 & 17 & 11 & 47 \\
SD Negeri 3 Kubutambahan & 75 & 29 & 65,38 & 12 & 16 & 17 & 58 \\
SD Negeri 4 Kubutambahan & 75 & 21 & 66,43 & 9 & 42 & 12 & 57 \\
SD Negeri 5 Kubutambahan & 68 & 33 & 61,39 & 11 & 33 & 21 & 63 \\
SD Negeri 6 Kubutambahan & 68 & 35 & 62,63 & 14 & 40 & 21 & 60 \\
\hline
\end{tabular}




\begin{tabular}{ccccccccc}
\hline \multirow{2}{*}{ Nama Sekolah } & \multirow{2}{*}{ KKM } & \multirow{2}{*}{$\begin{array}{c}\text { Jumlah } \\
\text { Siswa }\end{array}$} & \multirow{2}{*}{$\begin{array}{c}\text { Rata- } \\
\text { rata }\end{array}$} & \multicolumn{2}{c}{ Tuntas } & \multicolumn{2}{c}{ Tidak Tuntas } \\
\cline { 5 - 9 } & & & & Jumlah & (\%) & Jumlah & (\%) \\
\hline SD Negeri 7 Kubutambahan & 70 & 17 & 62,94 & 8 & 47 & 9 & 52 \\
\hline & (Sumber. Wali kelas III di SD & Gugus II Kecamatan Kubutambahan)
\end{tabular}

Berdasarkan tabel tersebut, tampak bahwa persentase siswa yang tuntas berkisar dari $16 \%-47 \%$, hal tersebut menandakan masih banyak siswa yang belum memenuhi nilai Kriteria Ketuntasan Minimal (KKM). rata-rata nilai UTS IPA siswa Sekolah Dasar kelas III di Gugus II Kecamatan Kubutambahan dapat dikatakan masih rendah karena tidak ada persentase ketuntasannya mencapai $50 \%$ atau di atas $50 \%$.

Hasil wawancara dan pencatatan dokumen diperkuat dengan hasil observasi, yang dilakukan pada tanggal 4 Januari 2018 hingga 10 Januari 2018 didapatkan hasil observasi yaitu: 1) pada saat guru bertanya, hanya beberapa siswa yang menjawab, 2) sebagian besar siswa tidak dapat menjelaskan kembali tentang konsep yang telah dipelajari, 3) guru hanya meminta siswa untuk mengerjakan pertanyaan-pertanyaan yang ada dibuku, itu artinya guru masih terpaku pada buku teks saja.

Berdasarkan permasalahan tersebut, maka perlu dicarikan suatu solusi. Salah satu solusi tersebut yaitu dengan menggunakan pembelajaran kreatif dan inovatif. Sejalan dengan hal itu pembelajaran kreatif dan inovatif diharapkan dapat memupuk kerjasama, menciptakan suasana belajar yang menarik dan menyenangkan serta melibatkan siswa secara langsung dalam proses pembelajaran, sehingga berdampak pada proses pembelajaran yang diinginkan.

Salah satu upaya pembelajaran yang sesuai untuk menyelesaikan masalah tersebut adalah merancang pembelajaran dengan menggunakan model pembelajaran yang menarik. Model pembelajaran menarik yang dapat digunakan yaitu model pembelajaran scramble. Menurut Qamariah (2016) model pembelajaran scramble merupakan salah satu model pembelajaran yang dapat diterapkan untuk meningkatkan kemampuan berpikir kreatif siswa. Menurut Widiantari (2013) model pembelajaran scramble adalah model pembelajaran yang menyediakan kartu soal dan kartu jawaban yang diacak nomornya yang dapat memudahkan siswa dalam mencari jawaban dan mendorong siswa untuk belajar mengerjakan soal tersebut, serta dapat mendorong siswa untuk dapat memecahkan masalah dengan cepat. Menurut Suryaningtyas (2017) model pembelajaran kooperatif tipe scramble merupakan model pembelajaran yang menekankan kerjasama dalam kelompok kecil menggunakan kartu soal dan kartu jawaban, yang mengajak siswa mencari jawaban dengan cara menyusun huruf-huruf yang disusun secara acak sehingga membentuk suatu jawaban. Menurut Sudarmi (2017) model pembelajaran kooperatif tipe scramble merupakan model pembelajaran yang menekankan kerjasama siswa dalam belajar melalui metode menjawab pertanyaan atau soal dengan jawaban yang berupa huruf, kata, atau kalimat yang diacak sehingga menjadi kata, kalimat, atau paragrap yang utuh dan bermakna. Shoimin (2014:166) menyatakan bahwa "model pembelajaran scramble merupakan model pembelajaran yang mengajak siswa untuk menemukan jawaban dan menyelesaikan permasalahan yang ada dengan cara membagikan lembar soal dan lembar jawaban yang disertai dengan alternatif jawaban.". Citrasmi (2016) menyatakan bahwa model pembelajaran scramble adalah model pembelajaran yang menyediakan kartu soal dan kartu jawaban yang diacak nomornya yang dapat memudahkan siswa dalam mencari jawaban dan mendorong siswa untuk dapat memecahkan masalah dengan cepat. Sehingga siswa dituntut untuk berpikir kreatif dalam pembelajaran di dalam kelas, untuk dapat mengurutkan kata-kata dalam kunci jawaban menjadi kata yang logis. Dari pengertian tersebut dapat dipahami bahwa model pembelajaran scramble melibatkan siswa secara langsung dalam pembelajaran, memupuk kerjasama siswa, serta menciptakan suasana belajar yang menyenangkan.

Model pembelajaran tersebut dapat didukung dengan menggunakan media pembelajaran. Salah satu media pembelajaran yang dapat digunakan yaitu media gambar. Murti (2016) menyatakan media gambar merupakan salah satu media yang dapat memudahkan siswa memahami materi pelajaran. Selanjutnya Kustandi dan Sutjipto (2016) menyatakan media gambar adalah media yang paling umum digunakan, media yang paling mudah dimengerti, dan dinikmati oleh semua orang. Gambar atau foto berfungsi untuk menyampaikan pesan melalui gambar yang menyangkut indera pengelihatan.

Berdasarkan pemaparan tersebut, model pembelajaran scramble berbantuan media gambar memiliki pengaruh terhadap hasil belajar siswa. Namun besarnya pengaruh model pembelajaran scramble dengan bantuan media gambar tersebut belum dapat diketahui. 
Berdasarkan pemikiran tersebut maka dilakukan penelitian dengan judul "Pengaruh Model Pembelajaran Scramble Berbantuan Media Gambar Terhadap Hasil Belajar IPA Siswa Kelas III di SD Gugus II Kecamatan Kubutambahan Tahun Pelajaran 2017/2018".

Tujuan dari penelitian ini yaitu untuk mengetahui pengaruh yang signifikan model pembelajaran scramble Berbantuan media gambar terhadap hasil belajar IPA siswa kelas III di SD Gugus II Kecamatan Kubutambahan Tahun Pelajaran 2017/2018".

\section{Metode}

Tempat peneltian ini di SD Gugus II Kecamatan Kubutambahan pada rentang waktu semester genap tahun pelajaran 2017/2018. Penelitian ini merupakan penelitian eksperimen semu (quasi eksperiment) dengan rancangan nonequivalent posttest-only control group design) dapat dilihat pada gambar berikut.

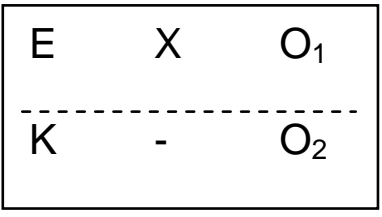

Gambar 1. Rancangan Penelitian

(dimodifikasi dari Agung, 2014)

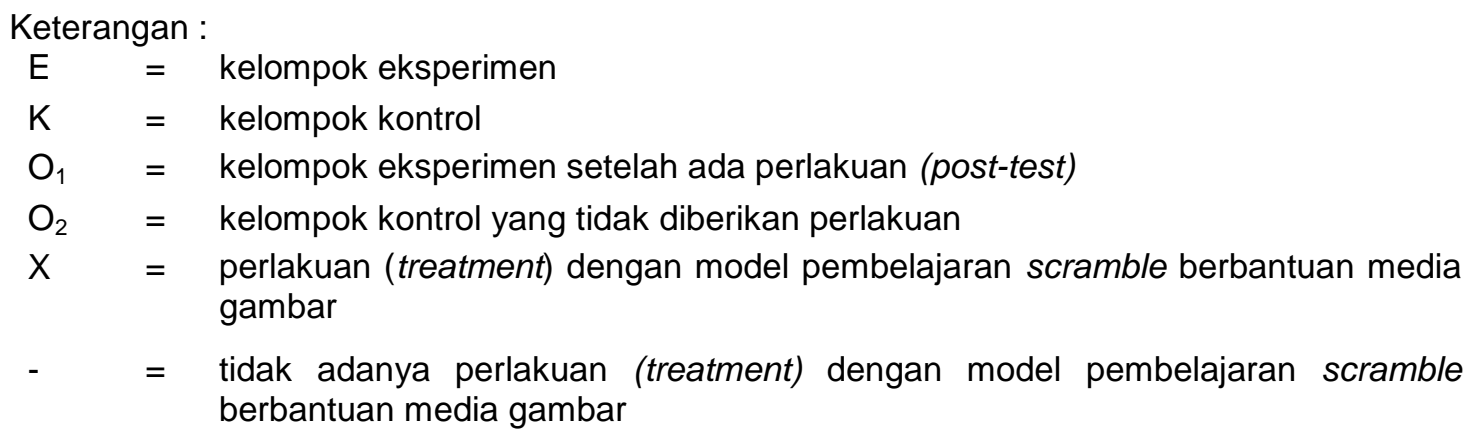

Pelaksanaan penelitian ini terdiri dari tiga tahap yakni tahap persiapan, tahap pelaksanaan, dan tahap pelaporan. Tahap persiapan terdiri dari merancang perangkat pembelajaran dan instrumen yang digunakan untuk penelitian, mengonsultasikan perangkat pembelajaran dan instrumen dengan pembimbing dan pakar, menguji instrumen yang digunakan untuk penelitian, melakukan analisis uji instrumen, merevisi instrumen penelitian yang telah dilakukan. Pada tahap pelaksanaan pertemuan diadakan sebanyak 10 kali pertemuan, 9 kali pertemuan untuk memberikan treatment dan 1 kali pertemuan untuk pemberian posttest. Langkah-langkah yang dilakukan pada tahap ini adalah memberikan perlakuan model pembelajaran scramble berbantuan media gambar pada kelas eksperimen dan pembelajaran dengan tidak menggunakan model pembelajaran scramble berbantuan media gambar pada kelas kontrol, kemudian mengadakan posttest pada kelas eksperimen dan kelas kontrol. Pada tahap pelaporan yang dilakukan adalah melakukan analisis data dilanjutkan dengan pengujian hipotesis sesuai data yang diperoleh dan menyusun laporan penelitian sesuai dengan analisis data yang didapatkan.

Populasi dalam penelitian ini adalah siswa kelas III di SD Gugus II Kecamatan Kubutambahan tahun pelajaran 2017/2018 yang menerapkan KTSP berjumlah 194 siswa. Sebelum menentukan sampel penelitian dilakukan uji kesetaraan populasi dengan Anava satu jalur. Berdasarkan hasil uji kesetaraan yang dilakukan pada 7 kelas populasi pada taraf signifikan $5 \%$ diperoleh nilai $F_{\text {hitung }}$ sebesar 1,97 dan nilai $F_{\text {tabel }} 2,15$ artinya seluruh siswa kelas III di Gugus II Kecamatan Kubutambahan memiliki kemampuan akademik yang setara. Pemilihan sampel dalam penelitian ini menggunakan teknik random sampling, didapatkan hasil bahwa SD Negeri 1 Kubutambahan yang berjumlah 36 siswa sebagai kelas eksperimen dan SD Negeri 6 Kubutambahan yang berjumlah 35 siswa sebagai kelas kontrol. 
Data yang dikumpulkan adalah hasil belajar IPA siswa kelas III. Untuk mengumpulkan data hasil belajar tersebut, dalam penelitian ini yang digunakan adalah metode tes. Jenis tes yang digunakan adalah tes objektif. Tes ini akan diberikan kepada siswa yang telah selesai mempelajari suatu materi atau pokok bahasan yang sudah diberi perlakuan. Bentuk tes dalam penelitian ini adalah tes objektif bentuk pilihan ganda (multiple choice item test. Setelah instrumen tersusun, terlebih dahulu dilakukan uji coba. Hasil uji coba tersebut akan dianalisis untuk mengetahui tingkat uji validitas tes, reliabilitas tes, tingkat kesukaran, dan daya beda. Namun sebelum melakukan uji lapangan terlebih dahulu dilakukan uji validitas isi oleh para pakar di bidang IPA. Berdasarkan hasil uji pakar, diketahui instrumen penelitian tes hasil belajar memiliki kategori sangat tinggi. Selanjutnya instrumen yang telah mendapat pertimbangan para pakar kemudian diujicobakan untuk mendapatkan gambaran umum secara empirik apakah instrumen hasil belajar layak digunakan sebagai instrumen penelitian. Tes yang akan diujikan adalah tes objektif yang terdiri atas 40 butir soal yang diberikan kepada 60 testee. Hasil analisis menunjukkan 34 butir tes yang valid dengan reliabilitas 0,82 ini berarti tes yang diujicobakan tergolong sangat tinggi. Hasil tingkat kesukaran tes diperoleh 13 butir soal tergolong mudah, 24 butir soal tergolong sedang, dan 3 butir soal tergolong sukar. hasil analisiss uji daya beda butir tes hasil belajar IPA, diperoleh 8 butir soal terklarifikasi kurang baik, 18 butir soal terklarifikasi cukup baik, dan 14 butir soal terklarifikasi baik.

Berdasarkan hasil pengujian instrumen, diperoleh 30 butir soal tes objektif yang digunakan untuk tes akhir (post-test). Pada penelitian ini, digunakan dua metode analisis yaitu metode analisis statistik deskriptif dan analisis statistik inferensial. analisis statistik deskriptif digunakan untuk mengetahui tinggi rendahnya kualitas dua variabel yaitu model pembelajaran dan hasil belajar siswa. Analisis statistik deskriptif dilakukan terhadap nilai rata-rata (mean), data tengah (median), data yang paling banyak muncul (modus), dan standar deviasi. Analisis statistik inferensial meliputi uji prasyarat analisis dan uji hipotesis. Uji prasyarat ada dua yaitu uji normalitas sebaran data dan uji homogenitas varians. Untuk menguji hipotesis yang telah dirumuskan pada penelitian ini digunakan uji-t sampel tidak berkorelasi dengan rumus polled varians.

\section{Hasil dan Pembahasan}

Data pada penelitian ini adalah hasil belajar IPA siswa yang diperoleh setelah diberikan perlakuan dengan menggunakan model pembelajaran scramble berbantuan media gambar pada kelompok eksperimen dan perlakuan yang tidak menggunakan model pembelajaran scramble berbantuan media gambar pada kelompok kontrol. Analisis data dilakukan pada masing-masing kelas yaitu eksperimen dan kelas kontrol. Adapun hasil analisis data statistik disajikan pada tabel sebagai berikut.

Tabel 2. Rekapitulasi Deskripsi Data Hasil Proses Kognitif

\begin{tabular}{lcc}
\hline \multicolumn{1}{c}{ Statisik } & Kelompok Eksperimen & Kelompok Kontrol \\
\hline Mean & 25.33 & 17,00 \\
Median & 26 & 16,55 \\
Modus & 27 & 15,2 \\
Varians & 7,83 & 14,4 \\
Standar Deviasi & 2,79 & 3,79 \\
\hline
\end{tabular}

Data hasil belajar IPA kelompok eksperimen dapat disajikan ke dalam kurva poligon sebagai berikut. 


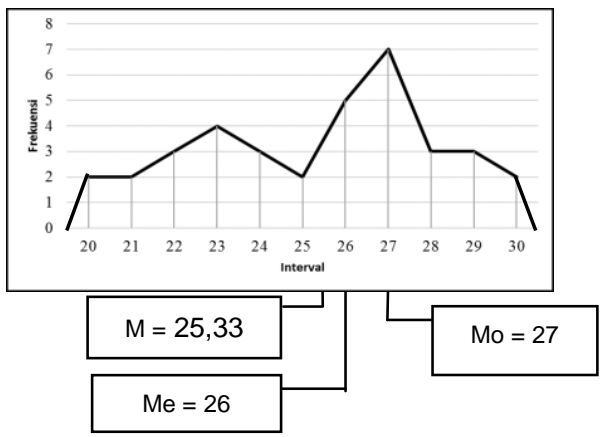

Gambar 2. Kurva Poligon Data Hasil Belajar IPA Kelompok Eksperimen

Dari data tersebut dapat diketahui bahwa mean lebih besar dari median, dan median lebih besar dari modus (M>Me>Mo). Dengan demikian, kurva poligon tersebut membentuk kurva juling positif yang berarti sebagian besar skor cenderung rendah. Untuk mengetahui kualitas dari variabel hasil belajar IPA siswa pada kelas kontrol, skor rata-rata hasil belajar IPA siswa dikonversikan dengan menggunakan kriteria rata-rata ideal dan standar deviasi ideal berdasarkan hasil konversi nilai rata-rata hasil belajar IPA kelompok eksperimen adalah 17,00 terletak pada rentangan $12,5 \leq \overline{\mathrm{X}} \leq 17,5$ dan berada pada kategori sedang.

Sebelum uji hipotesis, terlebih dahulu dilakukan pengujian prasyarat yang meliputi uji normalitas sebaran data dan uji homogenitas varians. Uji normalitas sebaran data dilakukan untuk membuktikan bahwa kedua sampel tersebut berdistribusi normal. Berdasarkan hasil perhitungan menggunakan rumus Chi-Kuadrat, diperoleh $\chi_{\text {hitung }}^{2}$ hasil posttest kelompok eksperimen adalah 6,984 dan $\chi^{2}$ tabel pada taraf signifikansi $5 \%$ dan $\mathrm{dk}=8$ adalah 15,507 . Hal ini berarti, $\chi^{2}{ }_{\text {hitung }}$ hasil belajar IPA kelompok eksperimen lebih kecil dari $\chi^{2}$ tabel $\left(\chi^{2}{ }_{\text {hitung }}\right.$ $\left.\chi^{2}{ }_{\text {tabel }}\right)$, sehingga data skor hasil belajar IPA kelompok eksperimen berdistribusi normal. Sedangkan $\chi^{2}$ hitung hasil belajar IPA kelompok kontrol adalah 4.095 dan $\chi^{2}$ tabel dengan taraf signifikansi $5 \%$ dan $\mathrm{dk}=3$ adalah 7,815. Hal ini berarti, $\chi^{2}$ hitung hasil belajar IPA kelompok kontrol lebih kecil dari $\chi_{\text {tabel }}^{2}\left(\chi^{2}\right.$ hitung $<\chi^{2}$ tabel $)$, sehingga data hasil belajar IPA kelompok kontrol berdistribusi normal.

Selanjutnya dilakukan uji prasyarat yang kedua yaitu uji homogenitas varians. Uji homogenitas varians data hasil belajar IPA dianalisis dengan uji $\mathrm{F}$ dengan kriteria dalam pengujian yaitu jika $F_{\text {hitung }}<F_{\text {tabel }}$, maka kedua kelompok data homogen. Sebaliknya jika $F_{\text {hitung }}>$ $\mathrm{F}_{\text {tabel}}$, maka kedua kelompok data tidak homogen (heterogen) Uji dilakukan pada taraf signifikan $5 \%$ dengan df1 $=k-1$, dan df2 $=n-k$. berdasarkan hasil Uji-F, diperoleh $F_{\text {hitung }}$ hasil belajar IPA kelompok eksperimen dan kelompok kontrol adalah 1,84, sedangkan $F_{\text {tabel }}$ pada $\mathrm{df}_{1}=\mathrm{k}-1$ $=2-1=1$, dan $\mathrm{df}_{2}=\mathrm{n}-\mathrm{k}=71-2=69$, dengan taraf signifikansi $5 \%$ adalah 3,98 . Hal ini berarti, varians data hasil belajar IPA kelompok eksperimen dan kelompok kontrol adalah homogen.

Berdasarkan hasil uji prasyarat analisis, diketahui bahwa data hasil belajar IPA kelompok eksperimen dan kelompok kontrol berdistribusi normal dan homogen. Selanjutnya dilakukan pengujian hipotesis penelitian dengan menggunakan uji-t. rumus uji-t yang digunakan adalah polled varians $\left(n_{1} \neq n_{2}\right)$ dengan kriteria pengujian adalah $\mathrm{H}_{0}$ ditolak jika $t_{\text {hitung }}>t_{\text {tabel }}$, dan $\mathrm{H}_{0}$ diterima jika $t_{\text {hitung }}<\mathrm{t}_{\text {tabel }}$ pada taraf signifikansi $5 \%$ dengan derajat kebebasan $\mathrm{db}=\mathrm{n} 1+\mathrm{n} 2$ 2. Adapun hasil analisis uji-t disajikan pada tabel sebagai berikut.

Tabel 3. Hasil Uji-t

\begin{tabular}{lcccccc}
\hline \multicolumn{1}{c}{ Kelompok } & $\mathbf{N}$ & $\mathbf{D b}$ & Mean $(\bar{x})$ & $\mathbf{s}^{\mathbf{2}}$ & $\mathbf{t}_{\text {hitung }}$ & $\mathbf{t}_{\text {tabel }}$ \\
\hline Eksperimen & 36 & \multirow{2}{*}{69} & 25,33 & 7,83 & \multirow{2}{*}{10,6} & \multirow{2}{*}{1,99} \\
Kontrol & 35 & & 17,00 & 14,4 & & \\
\hline
\end{tabular}


Perbedaan pembelajaran antara kelompok eksperimen dengan kelompok kontrol, tentunya berdampak pada hasil belajar yang diperoleh siswa. Hasil uji hipotesis menunjukkan bahwa $t_{\text {hitung }}$ lebih besar dari $t_{\text {tabel }}\left(t_{\text {hitung }}>t_{\text {tabel }}\right)$, yaitu $t_{\text {hitung }}=10,6>t_{\text {tabel }}=1,99$. Hal ini berarti $H_{1}$ diterima dan $\mathrm{H}_{0}$ ditolak, sehingga hasil penelitian ini menunjukkan bahwa terdapat pengaruh yang signifikan model pembelajaran scramble berbantuan media gambar terhadap hasil belajar IPA siswa kelas III di SD Gugus II Kecamatan Kubutambahan Tahun Pelajaran 2017/2018.

Besarnya pengaruh antara kelompok eksperimen yang diberikan perlakuan dengan menggunakan model pembelajaran scramble berbantuan media gambar dan kelompok kontrol yang tidak diberikan perlakuan berupa model pembelajaran scramble berbantuan media gambar dapat dilihat dari hasil analisis statistik deskriptif antara kedua kelompok tersebut. Berdasarkan hasil analisis statistik deskriptif, rata-rata hasil belajar IPA pada kelompok eksperimen adalah 25,33 yang berada pada kategori sangat tinggi dan kelompok kontrol adalah 17,00 yang berada pada kategori sedang. Selain itu, kelompok eksperimen memiliki skor yang sebagian besar cenderung tinggi dan kelompok kontrol memiliki skor yang cenderung rendah, hal tersebut dapat dilihat dari kurva poligon masing-masing kelompok.

Hasil penelitian ini telah membuktikan hipotesis yang diajukan, yaitu terdapat pengaruh yang signifikan model pembelajaran scramble berbantuan media gambar terhadap hasil belajar IPA siswa kelas III di SD Gugus II Kecamatan Kubutambahan Tahun Pelajaran 2017/2018. Hal tersebut dipengaruhi oleh beberapa hal sebagai berikut.

Pertama, model pembelajaran scramble, lebih menekankan proses pembelajaran yang berpusat pada siswa. Hal tersebut dikarenakan siswa terlibat secara aktif untuk menggali pengetahuannya sendiri melalui belajar berkelompok, guru hanya sebagai fasilitator dalam pembelajaran seperti menyiapkan sumber belajar dan media pembelajaran. Melalui pembelajaran seperti ini siswa akan mampu saling bertukar pikiran dengan kelompok, sehingga materi yang dipelajari lebih lama dalam ingatan siswa. Hal tersebut sejalan dengan penelitian yang dilakukan oleh Murti (2016) yang menyatakan bahwa, model pembelajaran scramble dapat dipahami sebagai pembelajaran student centered dengan guru berperan sebagai moderator dan fasilitator sedangkan siswa secara aktif mengkonstruksi pengetahuannya sendiri melalui belajar berkelompok untuk mendapatkan pengetahuan secara langsung. Hal tersebut juga sejalan dengan pendapat Astuti (2017) yang menyatakan bahwa model pembelajaran scramble merupakan model pembelajaran yang berpusat pada siswa, siswa diajak terlibat langsung dalam pembelajaran melalui belajar kelompok dan pengamatan secara langsung dilingkungan sekolah dan lingkungan sekitar siswa.

Kedua, model pembelajaran scramble merupakan model pembelajaran dengan menggunakan LKS berupa kartu soal dan kartu jawaban yang sebelumnya jawaban telah diacak sedemikian rupa untuk kemudian disusun menjadi jawaban yang benar. Melalui penggunaan kartu soal dan kartu jawaban tersebut dapat mendorong dan membantu siswa untuk memecahkan permasalahan, dan pembelajaran menjadi lebih menarik dan menyenangkan. Hal tersebut sejalan dengan pendapat yang dilakukan oleh Artini (2014) yang menyatakan bahwa penggunaan kartu soal dan kartu jawaban dapat digunakan oleh guru dalam mengembangkan kemampuan siswa dalam berpikir, dan mendorong siswa memecahkan masalah. Hal senada juga diungkapkan oleh Suryanta (2014) yang menyatakan bahwa penggunaan kartu soal dan kartu jawaban dalam proses pembelajaran mampu menarik perhatian siswa untuk belajar, dan mendorong siswa untuk mengerjakan soal tersebut.

Ketiga, dalam pembelajaran juga menggunakan media gambar sebagai media penyampaian materi yang dapat membantu siswa untuk lebih memahami materi pelajaran. Penggunaan media gambar membuat proses pembelajaran menjadi lebih menarik dan kontekstual. Penggunaan media gambar juga dapat membantu siswa untuk memusatkan perhatian terhadap materi yang disampaikan. Sehingga, dengan media gambar peserta didik dapat lebih memperhatikan benda-benda atau hal-hal yang belum pernah dilihatnya yang berkaitan dengan pelajaran. Hal tersebut sejalan dengan penelitian yang dilakukan oleh murti (2016) yang menyatakan bahwa penggunaan media gambar dalam menyampaikan materi pelajaran selalu dikaitkan dengan masalah yang kontekstual atau dikaitkan dengan pengalaman siswa dalam kehidupan sehari-hari. Selain itu dalam pembelajaran menggunakan media gambar yang dapat membantu siswa mengerti dan memahami materi pelajaran seperti media gambar. Hal senada dikemukakan oleh Citrasmi (2016) yang menyatakan bahwa penggunaan media gambar dalam pembelajaran mampu menarik perhatian siswa dan mampu meningkatkan hasil belajar siswa.

Berbeda halnya dengan kelas kontrol yang dibelajarkan dengan tidak menggunakan model pembelajaran scramble berbantuan media gambar, pertama guru memberikan materi 
kepada siswa, kemudian guru memberikan soal yang ada dibuku, selanjutnya siswa mengerjakan soal tersebut, kemudian guru dan siswa bersama-sama membahas, soal tersebut, dan terakhir guru memberikan evaluasi. Pada pembelajaran seperti itu guru lebih banyak memegang peranan dalam pembelajaran, sedangkan siswa hanya sebagai penerima apa yang disampaikan guru. Guru juga tidak menggunakan media dalam proses pembelajaran sehingga siswa hanya mendengarkan yang disampaikan guru. Pembelajaran seperti itu cenderung monoton dan kurang memotivasi siswa untuk belajar.

Oleh karena itu, terbukti bahwa terdapat pengaruh yang signifikan model pembelajaran scramble berbantuan media gambar terhadap hasil belajar IPA siswa kelas III di SD Gugus II Kecamatan Kubutambahan Tahun Pelajaran 2017/2018.

\section{Simpulan dan Saran}

Berdasarkan hasil analisis dan pembahasan penelitian, maka dapat disimpulkan bahwa skor rata-rata kelompok eksperimen sebesar 25,33, median sebesar 26, modus sebesar 27, standar deviasi sebesar 2,79, dan varians sebesar7,83. Data hasil belajar kelompok eksperimen membentuk kurva juling negatif dan skor rata-ratanya berada pada kategori sangat tinggi. Skor rata-rata kelompok kontrol sebesar 17,00, median sebesar 16,55, modus sebesar 15,16, standar deviasi sebesar 3,79, dan varians sebesar 14,4. Data hasil belajar kelompok kontrol membentuk kurva juling positif dan rata-ratanya berada pada kriteria sedang. Hasil perhitungan uji-t untuk uji hipotesis diperoleh $t_{\text {hitung }} 10,6$ sedangkan $f_{\text {tabel }}$ pada taraf signifikan $5 \%$ dengan $\mathrm{db}=36+35-2=69$ adalah 1,99. Ini berarti $t_{\text {hitung }}$ lebih besar daripada $t_{\text {tabel }}$ $(10,6>1,99)$, maka $H_{0}$ ditolak dan $H_{1}$ diterima. Dengan demikian, dapat disimpulkan bahwa terdapat pengaruh yang signifikan model pembelajaran scramble berbantuan media gambar terhadap hasil belajar IPA siswa kelas III di SD Gugus II Kecamatan Kubutambahan Tahun Pelajaran 2017/2018.

Berdasarkan simpulan hasil penelitian ini dapat diajukan saran-saran sebagai berikut. Kepada siswa disarankan agar siswa selalu memotivasi diri untuk belajar sehingga hasil belajar yang maksimal mampu dicapai, dan selalu menjaga kedisiplinan di dalam kelas. Kepada guru disarankan agar guru dapat menerapkan model pembelajaran scramble di kelas guna pencapaian hasil belajar siswa. Penerapan model pembelajaran ini hendaknya diimbangi dengan keaktifan guru memantau proses belajar siswa dan senantiasa memberikan arahan dan bimbingan agar kegiatan pembelajaran dapat berlangsung sesuai dengan tujuan pembelajaran yang dirancang. Kepada kepala sekolah disarankan agar hasil penilitian ini dapat dijadikan dasar-dasar pertimbangan untuk mengambil kebijakan yang paling tepat dalam membina guruguru untuk meningkatkan kemampuan mengelola proses pembelajaran di SD Negeri 1 Kubutambahan dan SD Negeri 6 Kubutambahan. Kepada peneliti lain disarankan bagi penelitian yang ingin melaksanakan penelitian sejenis, hendaknya, memperhatikan kelebihan dan kekurangan penelitian ini sehingga dapat digunakan sebagai acuan untuk mengembangkan penelitian yang akan dilakukan.

\section{Daftar Pustaka}

Agung, Anak. Agung Gede. 2014. Buku Ajar Metodologi Penelitian Pendidikan. Malang: Adiya Media Publishing.

Artini, A.A ayu Sri Vidya. 2014. "Pengaruh Model Pembelajaran Scramble Berbantuan Media Semi Konkret Terhadap Hasil Belajar IPS Siswa Kelas V SD Gugus Kapten Kompiang Sujana". Mimbar PGSD. Vol 2. No. 1 tersedia pada https://ejournal.undiksha.ac.id/index.php/JJPGSD/article/view/1880 (diakses tanggal 21 Desember 2017).

Astuti, Ni Made Dwi Kurni. 2017. "Pengaruh Model Pembelajaran Scramble Terhadap Hasil Belajar Bahasa Indonesia Siswa Kelas III Kecamatan Buleleng". Mimbar PGSD. Vol 5. No. tersedia pada https://ejournal.undiksha.ac.id/index.php/JJPGSD/article/viewfile/11024/7075 (diakses tanggal 21 Desember 2017).

Citrasmi, Ni Wayan. 2016. "Pengaruh Model Pembelajaran Scramble Berbantuan Media gambar Terhadap Hasil Belajar IPA di SD Negeri 1 Semarapura Tengah Kecamatan 
Klungkung". Mimbar PGSD. Vol 4. No. 1 tersedia pada https://ejournal.undiksha.ac.id/index. php/JJPGSD/article/view/8425 (diakses tanggal 21 Desember 2017).

Kustandi, Cecep dan Bambang Sutjipto. 2016. Media Pembelajaran Manual dan Digital Edisi kedua. Bogor: Ghalia Indonesia.

Masnati. 2017. Penerapan Model Pembelajaran Scramble untuk Meningkatkan Kemampuan Membaca Puisi Siswa Kelas V SD Negeri 020 Tembilahan Hilir. Jurnal PAJAR (Pendidikan dan Pengajaran) Program Studi Pendidikan Guru Sekolah Dasar FKIP Universitas Riau Volume 1 Nomor 2 Hal. 318-323. Tersedia Pada : https://media.neliti.com/media/publications/258081-penerapan-model-pembelajaranscramble-un-f16ff494.pdf.

Murti, I Gede Ari. 2016. "Pengaruh Model Pembelajaran Scramble Berbantuan Media Gambar Terhadap Hasil Belajar IPA Siswa Kelas IV SD di Gugus I Kecamatan Nusa Penida Semester Genap Tahun Pelajaran2015/2016”. Mimbar PGSD. Vol. 4 No. 1. Tersedia pada https://ejournal.undiksha.ac.id/index.php/JJPGSD/article/view/7522 (diakses tanggal 21 Desember 2017).

Qamariah, Nurul, Syifaul Gummah, dan Dwi Sabda Budi Prasetyo. 2016. Penerapan Model Pembelajaran Scramble untuk Meningkatkan Kemampuan Berpikir Kreatif Siswa. Jurnal Pengkajian IImu dan Pembelajaran Matematika dan IPA IKIP Mataram Vol. 4, No 1 Hal. 41-46. Tersedia Pada : https://media.neliti.com/media/publications/269540-penerapanmodel-pembelajaran-scramble-un-f6bb888a.pdf.

Shoimin, Aris. 2014. 68 Model Pembelajaran Inovatif dalam Kurikulum 2013. Yogyakarta: ArRuzz Media.

Sudarmi , dan Burhanuddin. 2017. Keefektifan Model Pembelajaran Kooperatif Tipe Scramble dalam Keterampilan Menulis Kalimat Bahasa Jerman Siswa Kelas XI SMA Negeri 11 Makassar. Eralingua : Jurnal Pendidikan Bahasa Asing dan Sastra Volume 1 No.1 Hal. 72-79. Tersedia Pada : https://ojs.unm.ac.id/eralingua/article/view/2991.

Suryanta, I Made. 2014. "Pengaruh Model Pembelajaran Scramble Berbantuan Media gambar Animasi Terhadap Hasil Belajar IPA Siswa Kelas V SD Gugus Yos Sudarso Denpasar". Mimbar PGSD Vol 2. No. 1. Tersedia pada http://download, portalgaruda.org/article.php?article=145601\&val=1342\&title=pengaruh\%20model\%20pe mbelajaran\%20Scramble20\%berbantuanmediagambaranimasi\%20terhadap\%20Hasilbel ajar\%20IPA\%20siswa\%20kelasV520gugusYosSudarso\%20Denpasar. (Diakses pada 21 Desembel 2018).

Suryaningtyas, Karlina. 2017. Pengaruh Model Pembelajaran Scramble dan Media Wayang terhadap Kemampuan Mengenal Jenis-Jenis Pekerjaan Siswa Kelas III SDN Ngadirejo Kediri. Simki-Pedagogia Vol. 01 No. 08 Hal. 1-11. Tersedia Pada : http://simki.unpkediri.ac.id/mahasiswa/file_artikel/2017/9df8ada558464a56d94f3213d663 2cf6.pdf.

Susanto, Ahmad. 2013. Teori Belajar dan Pembelajaran di Sekolah Dasar. Jakarta: Kencana.

Widiantari, Ni Nym., H. Syahruddin, I W. Widiana. 2013. Pengaruh Model Pembelajaran Scramble Berbantuan Media Video terhadap Hasil Belajar IPA Siswa Kelas IV SD di Gugus V Kecamatan Buleleng. Mimbar PGSD Undiksha Vol. 1 No. 1 Hal. 1-12. Tersedia Pada : https://ejournal.undiksha.ac.id/index.php/jjpgsd/article/view/819. 